\title{
EKSISTENSI KIAI DALAM PENGEMBANGAN TRADISI ISLAM INDONESIA
}

\author{
Sayfa Auliya Achidsti \\ Universitas Gadjah Mada (UGM) \\ Bulaksumur, Yogyakarta 55281 (+62-274) 588688 \\ E-mail: achidsti_sayfa@gmail.com \\ HP. +62-85293111066
}

Abstract: Locality is the closest entity toward the society. Moreover in Indonesia, this problem should be located as the stepping stone to view how the people live, their need, and the reason why do they live in such way. This existence relates each other forming a civil society. This article discusses the relationship between religion and society as an important factor which influences much on the Islamic scholars' position and all their activities in the society. In traditional Javanese society, the Islamic scholars are more positioned as having a strategic social function in a society.

Abstrak: Lokalitas merupakan unsur paling lekat dengan kehidupan masyarakat. Terlebih di Indonesia, persoalan lokalitas pada dasarnya hingga kini masih menjadi persoalan yang seharusnya diposisikan sebagai titik utama dalam memandang bagaimana masyarakat hidup, kebutuhankebutuhannya, hingga pada perbincangan mengenai alasan mengapa mereka tetap mempertahankan kehidupan bermasyarakatnya. Eksistensi lokal inilah yang pada akhirnya membentuk kesatuan yang saling terkait dalam bentuk masyarakat negara. Kajian ini menempatkan perihal hubungan agama dan masyarakat sebagai salah satu aspek determinan yang sangat mempengaruhi posisi kiai dan segala aktivitas yang dilakukannya dalam sebuah masyarakat, lebih lanjut, dalam membangun pranata sosialnya. Terdapat beberapa hal yang dapat dikatakan sebagai "modal" para kiai dalam melakukan proses pembangunan pranata sosialnya tersebut.

Kata Kunci: Kultur, Agama, Masyarakat, Politik, Kiai.

\section{A. Pendahuluan}

Kiai, memiliki pemaknaan yang beragam. Dari sisi istilah, secara umum 'kiai' diartikan sebagai penyebutan kepada seseorang yang dihormati yang 
memiliki ilmu keagamaan. Namun, secara luas, tent unya terdapat beberapa penafsirannya. Dalam percakapan di beberapa daerah, ajengan memiliki arti sinonim dengan kiai (Pusat Bahasa Diknas, 2008: 24). Ajengan memiliki makna sebagai orang yang terkenal, yang kemudian diikuti dengan penjelasan "terutama guru agama Islam". Dalam penjelasan tersendiri mengenai arti kata 'kiai', Kamus memiliki beberapa pengartian, yaitu: 1) sebutan bagi alim ulama (cerdik pandai-agama Islam); 2) alim ulama, misalnya; 3) sebutan bagi guru ilmu gaib (dukun, dsb); 4) kepala distrik (sebutan di daerah); dan 5) sebutan bagi benda yg dianggap bertuah (di keraton-keraton, senjata, gamelan, dsb, disebut dengan 'kiai'. Pemaknaan mengenai kata 'kiai' juga dapat diartikan sebagai seorang "ahli", yang berfokus pada bidang keagamaan.

Dalam kehidupan masyarakat di Indonesia, keberadaan kiai diposisikan dalam kelompok atas dalam struktur masyarakat. Kiai ditempatkan sebagai tokoh, yang karena dianggap memiliki kelebihan dalam hal ilmu pengetahuan agama dan kebijaksanaan, seringkali didatangi dan dimintai nasihat. Dalam kehidupan masyarakat modern, beberapa fungsi dari psikolog dalam hal layanan konsultasi terdapat dalam peran kiai terhadap lingkungan sekitarnya. Menurut Dhofier, secara teknis seseorang pantas dan berkembang untuk disebut sebagai seorang kiai adalah apabila telah memiliki pesantren, walaupun tidak menutup kemungkinan, tokoh yang tidak memiliki pesantren tetap dapat disebut kiai, tergant ung bagaimana karakter dan dinamikanya masing-masing (Dhofier, 1982).

Kiai, sebagaimana individu yang tersebar, dapat saja ada di desa atau kota. Kedua perbedaan dari sisi geopolitik tersebut tetap saja menempatkan kiai sebagai tokoh yang berada di atas daripada masyarakat biasa/kebanyakan. Mungkin dapat dibilang bahwa kiai merupakan golongan elite yang selalu dipandang oleh masyarakat sekitar dengan dimilikinya berbagai kelebihan yang melekat. Lombard, dalam Le Carrefour Javanais-nya (1990) (Lombard, 2008a), tidak terlalu menukik dalam membahas soal kiai. Namun, dia mengulas lebih detail santri dan menjadi pembicaraan yang menarik. Kalangan santri, yang oleh Lombard dikategorisasikan dalam kelompok "putih", berikut pesantren dan kiai di dalamnya, memiliki sember daya dalam hal aktivitas ekonomi. Hal ini yang pada perkembangannya akan turut mewarnai dinamika pertumbuhan budaya dalam masyarakat setempat. Bahkan, pada level tertentu, "santri kota", dengan segala kemampuannya dalam aktivitas perekonomian dan perdagangan, disebut oleh Lombard sebagai kelas borjuis kota (Lombard, 2008a). Tent unya, terlepas dari segala tendensi orientalis yang terdapat dalam tesis Lombard tersebut — mengingat Prancis adalah salah satu pusat perkembangan 
orientalisme - hal itu menampilkan pandangan dari sisi lain mengenai kalangan santri yang memiliki akses pada aktivitas perekonomiannya, sehingga dapat memiliki sumber daya ekonomi yang cenderung mapan. Dhofier, memaknai kekuatan sisi finansial pesantren, lebih khususnya lagi sumber daya pribadi kiai, sebagai hasil pertautan antara aktivitas perdagangan yang dilakukan, dan efek dari kharisma dan segala akses pada pusat kekuasaan karenanya. Efek dari segala hal yang dimiliki kiai, yang menimbulkan akses terhadap banyak sumber kekuasaan itulah yang kemudian berpengaruh pada kekuatan ekonomi kiai (Dhofier, 1982).

\section{B. Kultur dan Ketokohan}

\section{Pertumpuan Kultur Jawa}

Perkembangan agama Islam di Nusantara sendiri pada akhirnya memunculkan beragam hipotesis. Sejak Walisongo mulai menyebarkan agama Islam di Jawa pada sekitaran abad ke-14, pertautan Islam sebagai sebuah budaya kosmopolit dengan Jawa yang sangat bersifat statis dan magis, terjadilah sebuah bentuk yang unik dari keduanya. Dari sisi budaya, akulturasi kebudayaan adalah hal yang banyak diakui oleh para pengamatnya. Walaupun dikatakan demikian, sebenarnya hal tersebut agak sulit juga jika dikatakan telah terjadi akulturasi (pertemuan dua budaya); karena yang bertaut adalah aspek Islam sebagai jiwa, dan kejawaan (kejawen) sebagai sebuah budaya. Dua hal, misalnya, yang seringkali dipahami sebagai produk akulturasi Islam dengan Jawa adalah tradisi tahlilan dan pasar Sekaten; yang lebih tepat jika dibilang sebagai hasil dekonstruksi makna daripada akulturasi budaya. Namun, istilah 'sunan', yang merupakan penyebar agama Islam pada saat itu, tidak digunakan lagi saat ini dalam penyebutan kepada ahli/penyebar agama. Istilah tersebut menjadi perkecualian dengan sifat sakralnya, yang cenderung hanya diperuntukkan dalam penyebutan raja dan orang-orang tertentu yang diagungkan saja.

Memang, menjadi agak sulit kemudian dalam mendefinisikan kiai. Istilah kiai, bindere, nun, ajengan, dan guru adalah sebut an yang semula diperuntukkan bagi pada ulama tradisional di Pulau Jawa, walaupun sekarang kiai sudah cenderung dipergunakan secara generik bagi semua ulama, dan di Pulau Jawa maupun di luar Jawa (Wahid dalam Dirdjosanjoto, 1999). Jika kemudian bicara mengenai dinamika yang terjadi di Indonesia, di awal abad ke-20, politik berbasis agama tampak sangat menonjol dalam agenda dan aktivitas perpolitikan dalam negeri. Inilah yang kemudian memunculkan peristilahan baru antara kelompok tradisionalis dan kelompok puritan, yang agak merumitkan 
dalam pembahasan sosialnya, namun sekaligus membuatnya menarik jika ditilik dalam kaitannya dengan kajian politik. Definisi kiai, dalam penelitian ini tidak akan terlalu membatasi diri dengan dua faksionalisme yang ada tersebut; walaupun memang dengan adanya persoalan tersebut, akan sedikit banyak berpengaruh pada figur-figur tokoh yang akan diulas pada bab-bab berikutnya.

Satu hal yang harus diingat dalam pembahasan mengenai kiai adalah, kita tidak dapat melupakan bahwa kiai, dalam konteks ini, merupakan aspek dan faktor dalam pembentukan institusi sosial. Lebih jauh lagi, kiai bergerak dengan segala sumber daya dan implikasi serta akses — bahkan mungkin adanya eksesatasnya, dengan porsi yang cukup determinan dalam suatu arena yang pada perkembangannya disebut sebagai masyarakat itu. Masyarakat adalah sebuah arena tempat kiai tinggal, hidup, dan melakukan pembuktian eksistensinya sebagai manusia yang "berbeda" oleh karena kemampuannya dalam beberapa hal.

Hasil penelitian Geertz, The Religion of Java, dalam kajian ini menjadi salah satu naskah penting sebagai acuan kebudayaan di Nusantara, lebih khusus lagi, di Jawa. Agak berbeda dengan Geertz, Anderson dalam penelitiannya mengenai revolusi dan ketegangan sosial yang pernah terjadi di Surakarta pada sekitar 1945-1950, mencatat bahwa peta sosial abangan, santri, dan priyayi yang begitu kental terasa dalam permasalahan tersebut sulit untuk pisah mutlak dalam tiga kategori itu saja. Pada kenyataannya, terdapat golongan satria priyayi yang merupakan salah satu dari sekian pusat-pusat politik masyarakat. Golongan ini memegang posisi yang begitu strategis dan dukungan politik kuat dalam masyarakat dengan adanya dua karakteristik dalam dirinya, yaitu masyarakat santri dan kalangan priyayi. Golongan ini memiliki peran dalam pengurusan hukum syariat dalam masyarakat (Soejatno dan Anderson, 1974: 100).

Terlepas dari persoalan pelik para antropolog mengenai kategorisasi tiga kelompok masyarakat tersebut, perihal bahwa hasil penelitian tersebut adalah komprehensif dalam koridor penelitian kebudayaannya adalah hal yang cukup berguna dalam kajian ini. Juga nantinya, kumpulan tulisan Hurgronje (1992) yang akan menjelaskan dari sudut pandang masyarakat Jawa sendiri, karena pada jilid VII-nya itu, sebagaian besar bagian buku adalah surat dari pejabat daerah kepada yang ditujukan kepada Hurgronje sebagai korespondensi dan laporan. Persamaan antara dua literatur dari dua penulis tersebut menyajikan persepsi mengenai kiai bahwa entitas tersebut adalah bagian dari satu kelompok besar dalam masyarakat yang disebut dengan golongan santri. 
Walaupun di sini kriteria golongan santri menjadi kabur dengan pemaparan yang tidak mendalam dengan kurangnya telaah mengenai aktivitas yang berhubungan dengan peribadatannya, namun fakta bahwa kiai adalah bagian integral dari kalangan santri adalah benar adanya. Kekurangmendalaman mengenai pemahaman terhadap kaum santri tersebutlah yang pada akhirnya membawa hasil penelitian Geertz, dan banyak indonesianis lainnya, menimbulkan ketidakpercayaan para pembaca kalangan Indonesia sendiri. Kalangan pembaca Indonesia seringkali mengatakan bahwa kelompok yang dekat dengan agama sendiri terbagi-bagi. Tidak selamanya kelompok masyarakat yang dekat dengan agama dapat dipersatukan dalam satu kerangka yang menyebutnya sebagai satu kelompok yang homogen: santri. Noor, dalam karyanya, The Modernist Muslim Movement in Indonesia 1900-1942 (1973), mengatakan bahwa walaupun kalangan Islam seringkali disamakan dan digeneralisir dalam satu golongan, yaitu kelompok Islam, namun di situ pun terdapat banyak perbedaan, baik dalam hal syariat maupun prinsip dalam berpolitiknya. ${ }^{1}$

Perihal kiai, memang dapat kemudian ditarik pada pembicaraan mengenai ketokohan dalam masyarakat. Kiai, dengan penjelasan mengenai pemahaman umum masyarakat yang telah dijelaskan sebelumnya, dianggap sebagai seseorang yang memiliki kelebihan dalam hal ilmu, dan beberapa hal lain yang langka dimiliki oleh orang pada umumnya. Hal tersebut memposisikan kiai dalam tingkatan atas dalam sebuah struktur masyarakat. Namun, dengan menempati lokus atau lingkungan kehidupan di Nusantara, atau Jawa pada khususnya, budaya ketokohan yang sangat kuat dalam tatanan kehidupan masyarakatnya menambah kekuatan pada posisi kiai ini. Dalam konteks ketokohan ini, kiai dapat dibilang berdiri pada dua kaki, yaitu kultur setempat dan doktrin serta implikasi kultur agama.

Dalam kultur Jawa, istilah 'kiai' pun telah dipakai sebagai penyebutan tokoh yang dianggap memiliki kelebihan; namun, dalam konteks itu, kelebihan dari tokoh tertentu itu adalah dalam persoalan mistik. Pada tingkatan prinsip dasar yang melekat pada pribadi orang Jawa kebanyakan saja, persoalan tatanan dan penghormatan posisi dalam kehidupan sosial adalah hal yang sangat

\footnotetext{
${ }^{1}$ Buku ini adalah disertasi Deliar Noor di Universitas Cornell dan diterjemahkannya sendiri dalam bahasa Indonesia dalam Deliar Noor, Gerakan Moderen Islam di Indonesia 1900-1942, terj., (Jakarta: LP3ES, 1996). Mengenai pendapat umumnya terhadap perbedaan kalangan Islam di Indonesia, lihat pada bagian akhir bukunya di Bab Kesimpulan, hal. 316-344. Walaupun Deliar Noor adalah kalangan pembaharu (modernis) yang seringkali berbenturan dalam hal pemikiran dengan kaum tradisionalis yang menjadi fokus penelitian ini (kiai), namun sedikit catatannya dapat dijadikan referensi dari sudut pandang kesejarahan.
} 
penting. Mulder (2001) dalam karyanya Mysticism in Java; Ideology in Indonesia menekankan persoalan harmoni, yang selalu dijadikan landas tumpu orang Jawa dalam berkomunikasi dengan lingkungannya, tidak terkecuali selain manusia. Menjadi orang Jawa adalah menjadi berbudaya, yang artinya mengetahui cara-cara beradab dan sepenuhnya sadar akan posisi sosialnya. Seorang Jawa yang diakui adalah seseorang yang tahu tatanan (Mulder, 2001: 96). Walaupun Mulder dalam karyanya tersebut menuliskan kondisi masyarakat Jawa pada saat agama Islam telah masuk dan turut mewarnai kultur masyarakat setempat, dalam konteks penelitiannya tersebut masih terdapat nuansa kejawaan yang kental.

Persoalan hierarki, misalnya, adalah aspek yang turut mendukung posisi ketokohan dalam satu tingkatan atas dari piramida sosial. Bagaimanapun ketidaksederajatan moral akan muncul di manapun masyarakat itu berada. Kembali lagi, persoalan ini muncul sebab adanya perbedaan-perbedaan kemampuan yang di masing-masing tempat akan menimbulkan implikasi/ dampak yang berbeda pula. Namun, yang jelas, derajat moral yang berbeda, atas dan bawah, secara umum ada oleh karena adanya penghargaan sekeliling individu pada kelebihan atau kekurangan yang ada pada dirinya. Analogi yang paling sederhana yang dapat memunculkan kecenderungan penghargaan at as kelebihan seseorang dan kondisi hierarkis adalah analogi komunikasi anak dengan orangtua. Orangtua ada dengan kemampuan yang berbeda dengan anak secara mutlak, dan oleh karena itu, penghormatan anak terhadap orangtua adalah tindakan yang mutlak harus dilakukan sebab ketidaksederajatan antara keduanya itu. Namun, komunikasi anak-orangtua ini, secara tampilan permukaan, seringkali terlihat tidak hanya dalam kasus anak-orangtua saja, melainkan juga tampak pada hubungan bawahan-atasan, warga-pejabat, dan awambangsawan.

Dalam komentarnya mengenai kultur Jawa, Mulder banyak memberikan catatan mengenai kondisi hierarki ini. Dikatakannya bahwa kehidupan orang Jawa pada umumnya bergerak di antara kutub-kutub kasar dan kehalusan yang belakangan ini "tampaknya" lebih beradab. Bahasa dan tindak-tanduk diperlihatkan dan dipergunakan untuk mengekspresikan rasa hormat, penghormatan, dan penghargaan bagi yang berhak mendapatkannya. Bahasa dan tingkah laku mengekspresikan ideal pelestarian bentuk sosial yang tepat dan hubungan yang teratur.

Dengan prioritas pada tingkah laku demi "penjagaan" tatanan oleh pada orang Jawa tersebut, seringkali yang terjadi adalah kekakuan dalam tindaktanduk yang dilakukan. Etika, merupakan hal yang sangat penting dan selalu 
diperhitungkan oleh orang Jawa dalam kultur dan tradisinya. Hal ini kemudian membuat persoalan hierarki dalam masyarakat semakin tidak tergoyahkan oleh karena tingkah laku yang tidak sesuai dengan tradisi — pada umumnya, logika ini tentu sama dengan daerah-daerah lain - adalah sesuatu yang tabu. Dalam hal ini, kedua belah pihak melanggengkan posisinya masing-masing dalam struktur. Orang awam dalam menyikapi orang yang dianggap lebih tinggi derajatnya akan merendah dan meninggikan orang tersebut. Di sisi lain, tokoh bersangkutan akan menjaga wibawa yang telah dilekatkan kepadanya dengan adanya stat us sosial yang tinggi. Sikap merendah dan penjagaan wibawa yang dilakukan kedua belah pihak seperti itu, membuat pola tindakan dan tatanan selalu terjaga yang langgeng.

Sebelum Islam tumbuh, ada tiga lapisan pada masyarakat Jawa. Hal ini agak berbeda dengan beberapa teori mengenai tersebarnya agama Hindu-Budha dengan sistem kastanya yang cukup rumit yang dibawa dari tanah India. Secara umum, masyarakat Jawa terbagi dalam strukturasi lapisan masyarakat yang lebih menggambarkan kemampuan ekonomi-politik dalam hubungan sosialnya. Pertama, yaitu kaum agamawan Hindu dan Budha. Kelompok ini pada perkembangannya akan memiliki tanah bebas pajak dalam wilayah legal kerajaan setempat. Kedua, keluarga raja yang berkuasa at as para raka (penguasa) lokal dengan bantuan kaum agamawan. Dan, ketiga, yaitu masyarakat desa biasa yang dipungut pajak oleh raja dengan perantara para pemanen pajak (Ismawati dalam Amin, 2000).

Menjadi satu hubungan yang saling terkait antara satu elemen dengan elemen yang lain, tidak terkecuali dengan persoalan ekonomi, sosial, dan politik yang ditunjukkan dengan adanya strukturasi masyarakat tersebut. Terutama dalam masyarakat Jawa, adanya pembagian "kasta" mau tak mau akan mempengaruhi pola tindakan dan komunikasi antara kelompok masyarakat tersebut. Hal ini ada hubungannya dengan hakikat orang Jawa yang menganggap bahwa interaksi sosial dengan siapa dan apapun juga akan memiliki relevansi kelak atau di lain tempat (Widagdo dalam Amin, 2000: 65).

Oleh karena itu, tidak mengherankan pula, bahkan terkesan biasa, bahwa masyarakat Jawa menganggap raja adalah perwujudan dari para dewa yang harus dipatuhi segala perintahnya. Dalam pikiran orang Jawa, kosmos terbagi menjadi dua, yaitu mikrokosmos (dunia manusia, dunia nyata) dan makrokosmos (alam yang tidak terbayang, alam gaib, di luar batas pengetahuan manusia. Dan, konsep organisme kenegaraan orang Jawa meyakini bahwa raja adalah sebagai simbol dari pancaran mikrokosmos, atau negara itu sendiri; raja dianggap sebagai penghubung antara dua bentuk kosmos tersebut. Pada masa 
kejaraan Hindu, raja bahkan dianggap sebagai manifestasi ketuhanan dalam kehidupan mikrokosmos tersebut (Dhofier, 1982: 58). Raja ditempatkan pada tingkatan yang amat tinggi dalam masyarakat. Padahal, kembali diingat, bahwa kaum agamawan adalah pelantik para raja. Jadi, dalam pola kehidupan masyarakat Jawa, agamawan memang menempati posisi khusus pada dua sisi, di pemerintahan, dan di tingkatan warga.

\section{Pertumpuan Kultur Agama}

Di kaki yang lain, selain kultur setempat (Jawa), kiai berdiri pada kaki yang lain yaitu kultur agama. Yang jelas, setelah Islam masuk, terdapat beberapa perubahan prinsipil dalam sistem di masyarakat. Kaitannya dengan pandangan rakyat terhadap rajanya, misalnya, raja tidak lagi dianggap sebagai perwujudan dari dewa, melainkan wakil Allah di bumi (sebagai khalifatullāh) (Lombard, 2008b: 65). Dalam kaitannya dengan cara berpikir kaum muslim mengenai para pemimpin, secara umum, terdapat beberapa pengelompokan besar. Pengelompokan ini terjadi oleh karena — salah satunya namun paling jelas dan sebab utama - perbedaan terhadap cara memandang pemimpinnya dalam hubungannya dengan aspek kehidupan. Konsep tersebut, pada perkembangannya seringkali pembicaraannya menyentuh juga pada persoalan sosialpolitik, yang sudah bergerak secara mendunia dan sangat mempengaruhi perkembangan pemikiran berikut aktivitasnya (Achidsti, 2010). Pertama, pemikiran Sunni, ini secara umum merupakan cara berpikir yang berpandangan khalifah-sentris. Pemimpin menduduki posisi penting dengan kekuasaan yang luas. Walaupun masalah kepemimpinan (imāmah) bukan merupakan bagian dari rukun iman, rakyat ditunt ut untuk mematuhi kepala negara dengan kepatuhannya. Kedua, pemikiran Khawārij yang bersifat lebih "demokratis". Dalam hal khalifah (pemimpin), menurut mereka, jabatan itu terbuka bagi setiap lelaki muslim yang mampu berlaku adil, baik budak Afrika maupun yang merdeka. Jika seorang khalifah telah terpilih maka tidak dibenarkan turun tahta (Achidsti, 2010: 112). Ketiga, pemikiran Mu'tazilah, yang secara umum konsepsi ini menegaskan bahwa imāmah itu pilihan rakyat, tidak mesti berasal dari suku Quraysy, yang penting beragama Islam dan adil. Bagi Mu'tazilah, pengangkatan pemimpin tidak lagi wajib jika keadilan tidak ada lagi ada ancaman. Keempat, pemikiran Syi 'ah. Imāmah dalam Syi'ah mempunyai konotasi agama, bahkan merupakan bagian dari rukun iman yang harus diyakini selain tawhid, kenabian, kehidupan setelah mati, dan keadilan. Maka dari itu, pemimpin mempunyai kekuasaan penuh, baik agama maupun kekuasaan negara (Syafiuddin, 2007: 111). 
Terdapat banyak pendapat mengenai pengaruh Islam yang mana yang masuk dan tersebar di Nusantara; apakah itu penyebaran yang condong pada Islam yang dibawa dari tanah India, Cina, atau dari Timur Tengah. Namun, tentunya akan panjang penjelasan mengenai masing-masing pendapat tersebut. Hal yang jelas adalah arus Islam yang tersebar di Nusantara adalah Sunnī. Dalam konteks Indonesia, yang mengikuti pola pikir Sunnī ini, kedudukan pemimpin adalah hal yang sakral dan kepatuhan terhadapnya adalah hal yang penting untuk diperhatikan sebagai salah satu implikasi dari adanya arus Islam Sunni. Belum lagi dalam hal kelompok yang rekat hubungannya antaranggota seperti tarekat, yang pengaruhnya tidak hanya kepada anggota organisasinya saja, namun juga mempengaruhi lingkungan sekitarnya. Guru dalam tarekat ini, dianggap sebagai orang yang sangat dekat dengan Tuhan yang oleh sebab itu dianggap dapat melakukan komunikasi yang lebih baik dengan Tuhan. Dan, karena kiai juga seringkali berada dalam posisi pemimpin, entah itu secara administratif at au simbolik atau juga keduanya, maka kultur agama Islam adalah aspek yang turut menjadi pelanggeng posisi kiai pada atap struktur sosial.

Secara pandangan umum, kiai dianggap sebagai para penerus/pewaris nabi yang telah tiada. Para nabi, sebagai ut usan dari Tuhan dalam memperbaiki akhlak umat manusia, telah ditutup dengan keberadaan Nabi Muhammad SAW, sebagai nabi penutup/terakhir. Dalam pandangan Islam, ulama sebagai orang yang memiliki pengetahuan agama adalah pengganti para nabi dalam segala rujukan permasalahan umat. Dalam konteks di Indonesia, dan di dunia kebanyakan, al-Qur'an dan Hadis sebagai rujukan utama, pada kenyataannya hanya dimengerti oleh minoritas umat Islam. Sehingga, para ulama adalah rujukan umat; ulama memegang peran dan tugas kedakwahan yang diyakini sebagai kewajiban dalam jalan agama. Kiai, yang di sini merupakan penyebutan dari ulama, tak ubahnya adalah pemegang peran dan fungsi sosial yang penting dalam masyarakat beragama. Pemberontakan di Aceh dapat dijadikan salah satu contoh yang cukup jelas dalam kaitannya dengan ketundukan masyarakat terhadap para ulamanya di tengah pertentangan daerah tersebut dengan Negara. Para ulama, yang diyakini sebagai para pewaris agama, merupakan satu pusat politik yang dapat menggerakkan dengan mudah warga setempat untuk mendukung atau melawan Pemerintah (Barter, 2011: 20-26).

Telah dijelaskan mengenai bagaimana kiai sebagai perwujudan dari "agamawan yang tokoh" dalam masyarakat di atas yang berdiri pada dua kaki yang salah satu kakinya adalah kultur Jawa. Setelah Islam masuk, terjadi perubahan dalam pandangan tentang siapa yang dianggap sebagai wakil atau 
simbol dari kekuatan makrokosmos. Secara teori, teologi Islam telah menempatkan para penguasa negara dalam posisi yang tidak setinggi pada waktu jaman kerajaan Hindu dan Budha pada masa lampau. Di samping itu, secara teologis, Islam juga tidak mengakui adanya seorang manusia yang dapat dianggap sebagai simbol dari makrokosmos (Dhofier, 1982: 58). Namun, karena Islam beranggapan bahwa para ulama adalah pewaris para nabi, terdapat implikasi-implikasi yang menimbulkan efek serupa, yaitu penempatan posisi agamawan yang tinggi pula, walaupun dengan dasar yang berbeda. Di bawah kesultanan Islam, karena sultan diakui sebagai penguasa Islam, lembaga keagamaan mendapatkan pengakuan dan perlindungan penuh. Beberapa ulama menempati kedudukan yang tinggi dan terlibat dalam beberapa urusan kenegaraan yang penting. Dalam kedudukannya sebagai penasihat, bahkan beberapa ulama masuk dalam sistem administrasi pemerintahan, misalnya sebagai ketua Mahkamah Islam (Dirdjosanjoto, 1999: 35).

Dalam pada ini, terdapat pula konsep mengenai wali (waliyullāh), yaitu tingkatan yang dianggap lebih tinggi dari para ulama. Jika para ulama "hanya" dianggap sebagai para pewaris nabi dalam hal keilmuan dan pengetahuan agama serta contoh dalam akhlaknya, para wali seringkali dipahami sebagai orang yang dekat dengan Allah. Hal ini juga dapat dilihat dari pembentukan istilah wali itu sendiri yang berasal dari kata bahasa Arab 'waliy', yang diartikan sebagai orang "yang dicintai".

Konsep wali ini mengingatkan kita akan sejarah panjang Walisongo, yang merupakan sembilan dewan pendakwah agama Islam yang terkenal di tanah Jawa. Islam masuk sebagai gerakan penyebaran agama di wilayah Nusantara, terutama di Jawa, sering diidentikkan dengan kedatangan Walisongo. Peranan Walisongo ini sangat besar, baik dalam kehidupan politik kenegaraan dan juga sosial kemasyarakatan. Dalam Babad Cirebon, dikemukakan bahwa yang dimaksud dengan Walisongo adalah Sunan Bonang, Sunan Giri Gajah, Sunan Kudus, Sunan Kalijaga, Syekh Majagung, Maulana Maghribi, Syekh Bentong, Syekh Lemah Abang, dan Sunan Gunung Jati Purba. Namun, dalam Babad Tanah Jawi, kita tidak menemui nama Syekh Majagung, Syekh Bentong, dan Mawlānā Maghribī. Sebagai gantinya, akan dijumpai Sunan Ampel, Sunan Muria, dan Sunan Drajat (Sofwan, 2004).

Yang jelas, keberadaan Walisongo dalam negara dan masyarakat pada saat itu benar-benar memiliki peran penting. Kecenderungan bahwa agamawan seringkali diwaspadai, atau paling tidak, memiliki batas-batas demarkasi yang jelas antara penguasa dengan agamawan, telah terjadi sejak dulu. Pengalaman Eropa, misalnya, yang dicatat oleh Weber dalam Die Protestantische Ethik und 
der Geist des Kapitalismus (1905) mengatakan bahwa terdapat demarkasi antara kaum elite masyarakat dengan agama. Dikatakannya, orang-orang Katolik di Prancis pada lapisan kelas-kelas bawah paling tertarik dengan kenikmatan hidup, sedangkan orang-orang dalam lapisan yang lebih tinggi secara langsung bermusuhan dengan agama (Weber, 2003: 65).

Namun, dalam kondisi umum di Indonesia, pihak penguasa lebih sering mendekati kelompok agamawan; walaupun tentu tidak dapat dinafikan bahwa pendekatan pihak penguasa terhadap satu kelompok agamawan tertentu kadang juga tidak lepas dari pencarian dukungan untuk mendekati/melawan kelompok agama yang lain. Patut dicatat bahwa istri para wali tersebut diberi gelar dengan sebutan 'dewi'. 'Dewi' sendiri adalah bahasa Jawa yang berarti dewa perempuan, at au juga bidadari. Hal yang tampak dengan adanya penyebutan itu adalah penghormatan dari lingkungan sekitar para agamawan tersebut dalam rangka ungkapan pengagungannya. Dalam hal ini, menjadi menarik bahwa kemudian istri para kiai juga memiliki penyebutan tertentu, yaitu 'nyai', yang ditujukan dengan maksud sama dengan penyebutan 'dewi' bagi para istri sunan sebagai wujud rasa hormat terhadapnya.

\section{Persepsi Sosial}

Dalam berbagai literatur, perbincangan soal kiai selalu saja tidak pernah terlepas dari persoalan gerakan secara sosial. Tentu, dalam kajian ini pun nantinya, pembahasan yang dilakukan selain untuk melihat bagaimana proses tatanan dapat dibentuk oleh kiai, gerakan sosial para kiai adalah fokus utama yang lain. Gerakan dalam ranah sosial oleh kiai, bagaimanapun merupakan sebuah tindakan yang mengacu pada eksistensi kiai dalam lingkungannya. Pada perkembangan lebih lanjut lagi, aktivitas politik dari para kiai pun menjadi hal yang menarik, yang telah banyak dikaji oleh banyak penulis sebelumnya. Kajian mengenai gerakan sosial-politik dari para kiai ini tidak diragukan lagi disebabkan oleh ketertarikan para peneliti mengenai "dualisme" gerak kiai; yang di satu sisi merupakan pendakwah agama yang jauh dari sifat profan dan dilegitimasi sebagai orang suci, dan di sisi lain ranah aktivitasnya yang sangat luas membuatnya tidak dapat mengelak pula dari aktivitas politik.

Gelar sebagai kiai memiliki definisi yang agak berbeda dengan gelar sebagai ulama. Hal ini terlihat lebih pada konteks sosialnya. Walaupun jika kemudian kemampuan pengetahuan agama dari kedua gelar ini dalam tingkatan yang sama, kiai pada faktanya lebih dipandang tinggi dari ulama. Horikoshi menilai bahwa kiai memiliki nilai lebih daripada ulama. Secara tampilan fisik, Horikoshi menganggap bahwa sifat khas seorang kiai adalah terus terang, 
berani, dan cenderung blak-blakan (Horikoshi, 1987:47). Namun demikian, hal tersebut juga dipengaruhi oleh keunggulannya dalam memahami dan melakukan kontekstualisasi dalam masyarakat setempat, berikut dengan permasalahanpermasalahan lokal yang dihadapinya. Kiai dapat saja menjelaskan persoalan teologi yang rumit pada seorang petani yang awam dalam pendidikan formal maupun agama, namun dengan bahasa yang mudah dan lekat dengan permasalahan yang sedang dihadapinya. Dengan demikian, ide yang dibawa oleh kiai dapat dipahami pula oleh para petani, dan dapat menjadi solusi permasalahan yang sedang dialami.

Sebenarnya, perbedaan definisi antara dua gelar tersebut terdapat pada status dan pengaruh. Dalam kajian Geertz, kiai disebutnya sebagai makelar budaya (cultural broker) yang sanggup menyaring arus informasi yang masuk ke lingkungan santri, menularkan apa yang dianggap berguna, dan membuang apa yang dianggap dapat merusak bagi mereka. Namun, menurut Geertz, peranan penyaring itu akan macet pada saat arus informasi yang masuk begitu deras dan tidak mungkin lagi disaring oleh kiai. Dalam keadaan demikian, kiai akan kehilangan peranannya dalam perubahan sosial yang terjadi. akibat peranannya yang sekunder dan tidak kreatif, kiai akan mengalami kesenjangan budaya (cultural lag) dengan masyarakat di sekitarnya (Wahid dalam Horikoshi, 1987: xvii). Geertz mengatakan bahwa kiai adalah peran kepemimpinan yang efektif dalam konteks komunikasi dan transfer ide terhadap masyarakatnya (Geertz, 1960: 229-230). Dalam hal peranannya, kiai adalah seorang ahli dalam komunikasi dalam hal keislaman (agama) kepada massa petani dan kelas bawah. Sebagai sebuah usaha pengembangan sekolah agama, ia memiliki masa beradaptasi dan mendiami satu tempat tertentu dalam kurun waktu yang lama. Namun, dalam beberapa hal, secara konseptual kiai tidak juga bergerak hanya sebagai makelar budaya seperti yang diasumsikan oleh Geertz tersebut. Dalam banyak kasus, kiai sering berperan kreatif dalam perubahan sosial. Masalah yang dihadapinya adalah bagaimana kebutuhan akan perubahan itu dapat dipenuhi tanpa merusak ikatan-ikatan sosial yang telah ada sebelumnya, melainkan justru dengan memanfaatkan ikatan-ikatan itu sebagai mekanisme perubahan sosial yang diinginkannya (Wahid dalam Horikoshi, 1987: xvii).

Sebagai contoh dari adanya tindakan adaptatif yang dilakukan oleh kiai adalah pembangunan lembaga-lembaga pendidikan yang mulai dikembangkan arah dan pengaturan pengembangannya. Pondok pesantren tradisional mulai mengenai sistem yang agak lebih modern seperti kurikulum pengetahuan umum hingga pada alat-alat penunjang pendidikannya seperti meja dan kursi. Hal ini dilakukan oleh, misalnya, Wahid Hasjim, yang mengembangkan pola 
pendidikan pondok pesantrennya seperti itu. Walaupun kemudian muncul tanggapan-tanggapan negatif dan penolakan oleh beberapa kiai yang lain, namun pada akhirnya perkembangan metode pendidikan yang diterapkan Wahid Hasjim ini pelan-pelan diikuti pula oleh pesantren yang lainnya.

Dalam kasus yang lain, ustādz mursyīd (sebutan ustadz ini hanya panggilan yang berdasar kebiasaan masyarakat setempat di sana; karena pada kenyataannya, baik peranan, tugas, dan kharismanya lebih cenderung pada sosok kiai), dalam upayanya mendirikan lembaga pendidikan agama di daerah Sokaraja (Purwokerto) adalah pendekatan yang dapat dibilang cukup unik. Namun demikian, pendekatan semacam ini memang khas pendekatan yang digunakan oleh para kiai dalam menggerakkan masyarakat. Pertama, dengan stat usnya sebagai ahli agama di Sokaraja pada waktu itu (akhir tahun 1920-an), gelar sebagai ahli agama adalah status sosial yang sangat dihormati.

"Setelah diketahui orang banyak bahwa Mas Mursyid adalah seorang kiai atau ustadz, banyak orang membuatkan sebuah madrasah baginya, dan langgar Mbah Haji Abdul Fatah ini mendapat kehormatan menjadi gedungnya (Zuhri, 2001: 24)."

Kedua, seorang kiai dapat meyakinkan bahwa dirinya dan segala hal yang didirikannya adalah demi kepentingan dan kebutuhan masyarakat setempat. Oleh karena itu, kepercayaan masyarakat di sekelilingnya atas segala aktivitasnya mendapat dukungan penuh. Pada perkembangannya, masyarakat ikut menjaga atas apa yang dibangun oleh kiai bersangkutan.

"Satu kenyataan bahwa Ustādz Mursyìd telah berhasil menjadikan masyarakat merasakan bahwa madrasahnya adalah milik seluruh masyarakat. Bahwa masyarakat melekat menjadi satu dengan pesantrennya. Dengan demikian maka masyarakat mempunyai keberanian serta kemampuan untuk memikul segala keperluan madrasah ini, termasuk mendirikan gedungnya yang baru dengan 5 lokasi” (Ibid: 32).

Di sini, pernyataan Geertz bahwa kiai adalah makelar budaya menjadi kurang relevan. Definisi Geertz mengenai kiai ini tidak pas untuk ditempatkan dalam memahami sosok kiai secara umum. Makelar budaya sebagai peran dari kiai akan lebih tepat jika dilihat lebih pada satu peranan dari begitu luasnya peranan kiai dalam masyarakatnya. Kiai sebagai makelar budaya akan lebih tepat dipahami jika kondisi yang ada adalah bahwa kiai dalam masyarakat bersangkutan tersebut masih merupakan tokoh tunggal yang benar-benar menjadi sentral segala aktivitas masyarakat. Namun, tent unya kondisi masyarakat yang seperti ini akan sangat jarang ditemui. Bahkan, penelitian Geertz dalam Religion of Java-nya di Desa Mojokuto pun menunjukkan bahwa 
masyarakat santri yang menjunjung tinggi sosok kiainya tidak lagi mengkondisikan kiai sebagai satu-sat unya jalan masuk informasi yang datang ke masyarakatnya. Terdapat perkembangan-perkembangan dalam konteks sosial yang membuat informasi (dan budaya) yang masuk tidak lagi harus melalui kiai. Walaupun memang tidak dapat disangkal bahwa kiai memiliki peranan yang masih sangat menentukan dalam penilaian masyarakat atas informasi yang mereka terima itu baik atau tidak dengan pendapat kiai, namun perubahan sosial yang dihasilkan dari masuknya informasi sedikit banyak akan mengubah pula peranan kiai sebagai makelar budaya.

Dalam kaitannya dengan makelar budaya ala Geertz, situasi yang memungkinkan untuk terjadinya kondisi seperti itu adalah jika terdapat ancaman dari luar yang dirasa ole masyarakat merugikan mereka. Misalnya, ketidakstabilan kondisi politik dengan banyaknya pemberontakan yang terjadi. Kiai yang seringkali memegang peranan sebagai pelindung sekaligus penggerak massa masyarakat mendapatkan momennya untuk menjalankan peran sebagai makelar budaya, dalam artian dapat menyaring informasi yang datang. Dalam kasus lainnya, persoalan pertarungan ideologi antara kaum puritan dan tradisionalis, masyarakat di bawah kiainya masing-masing menempatkan diri mereka pada posisi taqlid yang cenderung diterapkan secara mutlak, oleh karena minimnya pemahaman agama dari masing-masing kelompok masyarakat. Jadi, informasi mengenai persoalan agama, terlebih yang menyangkut perdebatan doktrinal, dipercayakan pada kiai.

Sejak awal abad ke-19, gerakan lokal maupun yang mulai mendekati ke arah gerakan nasionalis tumbuh dan menyebar. Dalam periode ini, muncul beberapa organisasi yang mewadahi para tokoh lokal dan aktivis yang mengkonsolidasikan diri pada satu tujuan tertentu. Di tiap-tiap daerah telah bermunculan organisasi skala lokal dengan tujuan sosial kemasyarakatan walaupun kemudian yang dicatat sejarah adalah keberadaan organisasi Sarekat Islam (didirikan di Solo pada tanggal 11 November 1912) yang disebut-sebut sebagai organisasi kaum muslim yang pertama yang bersifat antaretnis. Sehubungan dengan contoh pada saat kependudukan Belanda di Nusantara, pemerintah Hindia-Belanda berkali-kali merasakan kekhawatiran yang sangat atas kemunculan kesadaran dari tokoh-tokoh lokal dalam gerakan resistensinya terhadap pemerintah. Perkataan Hurgronje mengenai kekhawatiran pihak pemerintah terhadap tokoh agama lokal,

“...syaikh dan pengikut mereka merupakan musuh-musuh yang paling berbahaya terhadap pemerintahan Hindia-Belanda, paling sedikitnya sama berbahayanya seperti kaum Sanusi terhadap kekuasaan Prancis di Aljazair" (Hurgronje, 1992: 76). 
Berbagai peraturan dikenakan terhadap para tokoh agama di daerahdaerah. Dalam hal ini, selain pembatasan organisasi yang boleh dibentuk, pembatasan dan kontrol atas aktivitas pendidikan yang diadakan di masyarakat begitu menyusahkan para kiai dalam melakukan gerakan dakwahnya. Pada tahun 1905, pemerintah mengeluarkan perat uran yang mengharuskan para guru agama Islam memiliki ijin khusus untuk dapat mengajar; terutama ini untuk mengatur pergerakan para guru di Jawa. Hal itu diatur dalam Staatblad 1905 No.550, yang juga disebut dengan Guru Ordonantie 1905 (Peraturan Guru 1905). Peraturan ini mengharuskan ijin tertulis dari bupati atau pejabat setara dan adanya berbagai daftar rinci mengenai aktivitas pengajarannya. Tent unya hal ini sangat menjadi halangan, di mana para kalangan pesantren seringkali tidak begitu memperhatikan persoalan teknis dan berkas-berkas administratif. Kemudian, Ordonansi tahun 1932 (Ordonansi Sekolah Liar-Wilde Scholen Ordonanntie) mengharuskan mereka yang ingin memberikan pelajaran di sekolah yang tidak dibiayai pemerintah harus mempunyai ijin tertulis dari pemerintah sebelum beraktivitas. Lebih jauh, sebelum mengeluarkan ijin tersebut, pemerintah daerah setempat harus menanyakan persetujuan kepada inspektur pendidikan (Komarudin, Suara Pembaruan, 27 Februari 2007). Ditambah lagi beberapa syarat, bahwa harus lulusan sekolah pemerintah atau swasta yang bersubsidi (Noor, 1996: 191-200). Tent unya, hal ini membuat sekolah agama tertekan pertumbuhannya, dan lembaga pendidikan lain sulit berkembang.

Dengan kedudukan dalam struktur sosial yang diposisikan dalam tingkatan elite, kiai menjadi tumpuan bagi aspirasi dan kebutuhan masyarakat di sekitarnya. Oleh karena itulah, kiai dalam gerakannya juga tidak jarang, atau juga harus, bersentuhan dengan politik. Sejak masa awal kerajaan Islam di Nusantara, para ulama telah memainkan peran penting. Bahkan, para raja di jaman dulu tersebut, proses penobatannya pun diharuskan melalui prosesi yang melibatkan para pemuka agama sebagai pelantik, atau paling tidak, kaum agama dilibatkan sebagai simbolisasi dukungan kalangan agama pada kenaikan tahtanya itu. Para penguasa yang baru dinobatkan harus bersandar pada para ulama, guru mistik, dan ahli kitab karena merekalah yang dapat menobatkan para penguasa tersebut menjadi pangeran-pangeran Islam, mengajar, serta memimpin upacara keagamaan, menjalankan hukum Islam terutama di bidang perkawinan, perceraian, serta warisan (Dirdjosanjoto, 1999: 35).

Secara umum, perjuangan merupakan satu kerangka keseluruhan dari peran kiai, menggambarkan cita-cita fundamental serta tujuan untuk tetap mempertahankan peran mereka dalam masyarakat. Menurut Horikoshi, 
keterlibatan dan keprihatinan politik kiai dalam turut memikirkan nasib masyarakat merupakan tugas sekunder dan pada saat bersamaan merupakan bagian yang penting dari perjuangan Islam. Kurang dapat dimengerti apa alasan Horikoshi untuk mengatakan bahwa tugas kiai dalam ranah perjuangan kemasyarakatan adalah tugas sekunder mengingat sejarah mengatakan bahwa tugas keagamaan dan sosial adalah dua sisi mata uang sebagai tugas para kiai. Horikoshi secara implisit menekankan bahwa fungsi keulamaan yang primer kemudian adalah fungsi keagamaan; bahwa peran ulama yang paling bernilai sebagaimana telah berlangsung adalah peran tradisional mereka sebagai penanggungjawab dalam mempertahankan keyakinan itu sendiri. Melalui pengajaran ilmu-ilmu agama, ulama melestarikan praktik-praktik ortodoksi keagamaan para penganutnya (Horikoshi, 1987: 114). Pernyataan Horikoshi mengenai fungsi keulamaan tersebut menjadi agak dapat diterima jika melihat bahwa Horikoshi melakukan penelitian dalam lokus kecil, yaitu satu desa dengan sedikit studi kasus ketokohan agama di situ. Walau demikian, terdapat banyak bukti lain dalam hal kekuatan para kiai menggalang kekuatan massa dalam sebuah perlawanan. Salah satunya adalah pada masa perang kemerdekaan pasca 1945 di Yogyakarta.

“...pondok pesantren Krapyak mempunyai peranan penting ikut membantu perjuangan mempertahankan kemerdekaan, terutama pada masa Agresi Militer Belanda II. Pada masa itu, pondok pesantren Krapyak dipimpin oleh K.H. Abdullah Affandi dan K.H. Abdul Qodir...sebagian besar santrinya ikut menggabungkan diri ke dalam kelompok-kelompok pejuang seperti Kesatuan Komaruddin..."(Tashadi, dkk., 2000: 73-74).

Geertz dalam Religion of Java-nya, yang dapat menjelaskan dalam lingkup Mojokuto sebagai generalisasi tipikal masyarakat yang ada di Jawa, mengatakan bahwa adanya perhatian masyarakat mengenai Islam dan doktrin agamanya adalah bukti hubungan erat agama (Islam) dengan masyarakat yang dapat mempengaruhi segala aspek kehidupan. Agama tidak hanya dipandang sebagai serangkaian kepercayaan semata-mata, sejenis filsafat, atau bahkan sebagai suatu sistem umum tentang nilai-nilai yang mengikat mereka sebagai individu. Sebaliknya, mereka memahami sebagai agama yang dilembagakan dalam kelompok sosial; kaum santri di sekeliling tempat tinggal warga. Bila berbicara mengenai Islam, di benak mereka yang ada hampir selalu tergambarkan sejenis organisasi sosial di mana kepercayaan Islam merupakan elemen yang menentukan. Itu mungkin berupa suatu organisasi amal, perkumpulan wanita, panitia masjid desa, sekolah, kantor jawatan agama setempat, atau partai politik mereka baik di tingkat lokal, regional, maupun nasional 
(Geertz, 1983:176-178). Dalam hal ini, terdapat sebuah kasus menarik pada masa pemerintahan kolonial Belanda di Indonesia di mana kiai penghulu di kampung ditarik menjadi bagian dari struktur pemerintahan kolonial di desadesa. Kelompok kiai/ulama penghulu ini sendiri menempati kedudukan dalam bidang kehakiman yang menyangkut penerapan hukum Islam. Sejak masa pemerintahan Gubernur Jenderal Deandles, pengulu di setiap kabupaten di wilayah kekuasaan gubernemen ditarik di dalam lingkungan pengadilan negeri (landraad) yang dibentuk oleh pemerintah (Isma'il, 1997: 65-66).

Dalam konteks sosio-politik, gerakan kiai pun sering ditopang dengan beberapa organisasi yang dapat mewadahi secara efektif dalam upaya dakwahnya. Nahdlatul Ulama (NU) yang merupakan organisasi kaum tradisionalis, diisi oleh para kiai. Perlu dijelaskan sebelumnya bahwa dalam pemahaman umum, pada perkembangannya dengan banyaknya dinamika sosial-politik di Indonesia, kiai sering diidentikan dengan kaum tradisionalis; di mana di sisi satunya, berdiri kaum puritan yang cenderung menggunakan cara-cara yang lebih mekanistik dan mengandalkan perkembangan metode-metode fundamentalistis dalam jalan dakwahnya.

Dalam organisasi NU ini, para kiai berkomunikasi satu dengan lain, dalam satu daerah atau antardaerah, untuk membicarakan mengenai bagaimana dakwah yang akan mereka lakukan ke depannya. Dan, menarik dikatakan di sini bahwa dakwah dan perkembangan yang ada dalam pemikiran para kiai tersebut tidak melulu soal agama, namun juga persoalan ekonomi, pendidikan, dan kesejahteraan sosial. Hal ini pun diakui Deliar Noor sebagai perbedaan antara ulama yang condong kepada arah gerakan purifikasi Islam dengan para kiai tradisionalis dalam pola pikir dakwah di masyarakatnya. Dikatakan Noor bahwa memang pada awal perkembangan Islam era kontemporer di Indonesia (sekitaran dari awal tahun 1900-an), para ulama puritan lebih mementingkan gerakan dakwah keagamaan, walaupun beberapa memang langsung menuju pengembangan kemasyarakatan (salah sat unya, misalnya, Muhammadiyah). Namun, pada umumnya, para ulama selalu menaruh perhatiannya pada masalah umat; yang tent unya selalu akan menyentuh persoalan kesejahteraan sosial juga.

Dalam konteks sayap gerakan NU, yang dewasa ini yang menjadi paling krusial keberadaannya adalah dalam pembicaraan tentang pengembangan warganya. IPNU (Ikatan Pelajar NU), IPPNU (Ikatan Pelajar Puteri NU), Gerakan Pemuda Ansor (kepemudaan), dan Fatayat (keputrian) merupakan badan anak organisasi NU yang diharapkan dan harus dimaksimalkan untuk dapat langsung mengurus persoalan masing-masing. Satu hal yang tidak kalah 
pentingnya adalah pada tingkatan mahasiswa sebagai elemen yang sangat mempunyai peran pada masa kini. PMII (Pergerakan Mahasiswa Islam Indonesia) adalah sebuah organisasi mahasiswa NU. PMII menjadi organisasi yang mewadahi pada kader mahasiswa NU yang melanjutkan pendidikannya pada tingkat perguruan tinggi. Gerakan-gerakan kepemudaan dan intelektual yang dimotori oleh konsep dan gerakan para kiai inilah yang dewasa ini sangat efektif dalam pengembangan wacana. Menjadi menarik bahwa mulai pada seputaran tahun 1980-an dengan maraknya kemunculan lembaga nonpemerintah (NGO) banyak di antaranya adalah para santri, yang sempat pula berproses sebelumnya pada organisasi-organisasi di atas. Dengan itu, dapat pula dimengerti bahwa peran kiai dalam sering membawa pengaruh penting, tidak hanya dalam soal kemasyarakatan di tingkat lokal kemudian, namun juga gagasan dan tren dalam skala nasional.

Namun demikian, hal yang sebenarnya paling diharapkan dalam sosok kiai adalah fungsi sosial-kemasyarakatannya itu sendiri. Dalam hal ini, memang pesantren sebagai institusi pendidikan yang dibentuk oleh kiai bersangkutan adalah kegiatan utama yang selalu diupayakan untuk ada. Hal tersebut pada banyak sisi dikarenakan sifat gerakan kiai sebagai aktivitas dakwah, mengubah kondisi menuju ke arah yang lebih baik. Pendidikan adalah aset utama dalam sebuah masyarakat sebagai prasyarat dari perubahan di masa yang akan datang. Walaupun demikian, upaya perubahan yang dilakukan oleh para kiai biasanya tidak terbatas hanya dengan mengadakan pendidikan dalam sebuah masyarakat. Pada kenyataannya, pondok pesantren lebih merupakan pusat peradaban sebuah masyarakat tertentu dengan perkembangan teknologi dan fasilitasfasilitasnya. Hal ini akan lebih tampak jika terjadi ketidakstabilan Negara dalam perannya terhadap masyarakat. Kiai dan institusi yang dibentuknya mengisi kekosongan oleh Negara dengan menyediakan segala hal yang dibutuhkan masyarakat sekitar. Dalam masa-masa kesulitan ekonomi yang dihadapi Indonesia pada tahun 1950 hingga 1960-an, misalnya, pembaruan yang diselenggarakan pesantren banyak berkenaan dengan pemberian keterampilan, khususnya dalam bidang pertanian (Azra, 1997: xiii). Hal ini dapat menunjang ekonomi pesantren itu sendiri sekaligus memperkuat kemandirian ekonomi dan pangan masyarakat sekitarnya.

\section{Simpulan}

Kajian ini pada akhirnya menempatkan kiai sebagai sebuah peran yang berada dalam sebuah posisi strategis dalam sebuah struktur masyarakat. Dalam hal ini, masyarakat Jawa diasumsikan dalam satu kultur yang memandang 
seorang tokoh agama sebagai manusia yang unggul, yang terkadang lebih jauh dari konteks primus inter pares karena memiliki dua modal utama yang berkaitan dengan kultur setempat. Pertama, tradisi dan pola pikir tradisional Jawa menempatkan kiai sebagai salah satu varian pemimpin, yang karena itu memiliki kelebihan dari manusia lain karena pengaruh cara pandang yang melihat pemimpin sebagai wujud dari kekuatan dewa. Lebih lanjut, pada perkembangannya, para pendakwah Islam ini mengubah pemikiran tersebut dan menempati posisi yang strategis dalam tradisi Jawa berhubungan dengan kepemimpinan dan politik, yaitu tokoh agama sebagai sebuah institusi yang berada berdampingan dengan kekuatan politik kerajaan, di antaranya sebagai pengesah pergantian kekuasaan dan penasihat keputusan politik kerajaan. Kedua, pertumpuan pada tradisi Islam, yang menempatkan para ulama sebagai para penerus nabi.

Namun, pada dasarnya hal-hal tersebut, pertumpuan pada tradisi Jawa dan perkembangan agama Islam, hanya sebagai faktor yang mendukung dalam kaitannya dengan pandangan dan penghormatan masyarakat terhadap para kiai. Pada perkembangannya, persepsi masyarakat terhadap kiai yang melihatnya sebagai tokoh yang berpengaruh dalam kehidupan sosial adalah satu aspek yang paling signifikan yang mempengaruhi pandangan masyarakat, sekaligus sebagai sebuah fungsi dan peran yang memunculkan eksistensi kiai. Sumbersumber ekonomi dan politik yang berada di sekeliling kiai adalah alasan mengapa kiai menjadi pusat pembangunan institusi sosial dalam masyarakat.

\section{Daftar Pustaka}

Achidsti, Sayfa Auliya. 2010. "Kontroversi Formalisasi Islam dan Kepanikan Retorika" (2010a), dalam jurnal Ibda Vol. 8, No. 2.

Azra, Azyumardi. 1997. "Pesantren: Kontinuitas dan Perubahan", sebagai "Kata Pengantar" dalam Nurcholish Madjid, Bilik-Bilik Pesantren. Jakarta: Penerbit Paramadina.

Barter, Shane Joshua. 2011. "Ulama, the State, and War", dalam Contemporary Islam, Vol. 5, No.1, hal. 20-26.

Dhofier, Zamakhsyari. 1982. Tradisi Pesantren: Studi tentang Pandangan Hidup Kyai. Jakarta: LP3ES.

Geertz, Clifford. 1960. "The Javanese Kijaji: The Changing Role of a Cultural Broker", dalam Comparative Studies in Society and History, Vol. 2, No. 2 (1960), hal. 229-230. 
1983. Abangan, Santri, dan Priyayi dalam Masyarakat Jawa,

Terj. Jakarta: Dunia Pustaka Jaya.

Horikoshi, Hiroko. 1987. Kiai dan Perubahan Sosial, terj. Jakarta: P3M.

Hurgronje, C. Snouck. 1992. Kumpulan Karangan Snouck Hurgronje, Jilid VII, Terj. Jakarta: INIS.

Isma’il, Ibnu Qoyim. 1997. Kiai Penghulu; Peranannya di Masa Kolonial. Jakarta: Gema Insani Press.

Ismawati. 2000. "Budaya dan Kepercayaan Jawa Pra-Islam”, dalam M. Darori Amin (Ed.), Islam dan Kebudayaan Jawa. Yogyakarta: Gama Media.

Komarudin. 2007. “75 Tahun Ordonansi Sekolah Liar”, dalam koran Suara Pembaruan, 27 Februari 2007.

Lombard, Denys. 2008a. Nusa Jawa: Silang Budaya. Jaringan Asia, Terj. Jakarta: Gramedia Pustaka Utama.

Mulder, Niels. 2001. Mistisisme Jawa; Ideologi di Indonesia, Terj. Yogyakarta: LKIS.

Noor, Deliar. 1996. Gerakan Moderen Islam di Indonesia 1900-1942, Terj. Jakarta: LP3ES.

Pusat Bahasa Departemen Pendidikan Nasional. 2008. Kamus Bahasa Indonesia. Jakarta: Departemen Pendidikan Nasional. 2008. Tesaurus Bahasa Indonesia Pusat Bahasa. Jakarta:

Departemen Pendidikan Nasional.

Soejatno dan Benedict Anderson. 1974. "Revolution and Social Tensions in

Surakarta 1945-1950", dalam Indonesia, Vol. 17 (Apr., 1974), hal. 100.

Sofwan, Ridin, dkk. 2004. Islamisasi di Jawa; Walisongo, Penyebar Islam di Jawa, Menurut Penuturan Babad. Yogyakarta: Pustaka Pelajar.

Syafiuddin. 2007. Negara Islam menurut Konsep Ibnu Khaldun. Yogyakarta: Gama Media.

Tashadi, dkk. 2000. Keterlibatan Ulama di DIY Pada Masa Perang Kemerdekaan Periode 1945-1949. Jakarta: Departeman Pendidikan Nasional.

Wahid, Abdurrahman. 1999. "Pengantar", dalam Pradjarta Dirdjosanjoto. Memelihara Umat: Kiai Pesantren-Kiai Langgar di Jawa. Yogyakarta: LKIS.

Weber. Max. 2003. Etika Protestan dan Semangat Kapitalisme, Terj. Yogyakarta: Pustaka Promethea.

Widagdo, Djoko. 2000. "Sikap Religius Pandangan Dunia Jawa", dalam M. Darori Amin (Ed.), Islam dan Kebudayaan Jawa. Yogyakarta: Gama Media. 
Ibdg' Jurnal Kebudayaan Islam

Zuhri, Saifuddin. 2001. Guruku Orang-Orang dari Pesantren. Yogyakarta: Pustaka Sastra LKIS. 